\title{
NILAI ANAK BERKEBUTUHAN KHUSUS DI MATA ORANGTUA
}

\author{
Suparmi \\ Fakultas Psikologi Universitas Katolik Soegijapranata \\ Semarang
}

\begin{abstract}
Abstrak
Tujuan penelitian ini adalah untuk melakukan eksplorasi bagaimana orangtua menilai anaknya yang memiliki kebutuhan khusus. Metode yang digunakan adalah pendekatan kualitatif. Responden penelitian adalah orangtua yang memiliki anak berkebutuhan khusus, yang sedang dalam masa perkembangan kanak-kanak sampai remaja awal (rentang usia dari 2 tahun sampai 13 tahun). Lokasi penelitian di kota Semarang. Data dikumpulkan melalui wawancara semi terstruktur. Proses analisa data meliputi verbalisasi data, open coding, axial dan selective. Hasil penelitian menemukan bahwa orangtua menilai anak berkebutuhan khusus dengan nilai secara psikologis, religi dan ekonomi.
\end{abstract}

Kata kunci: nilai anak berkebutuan khusus, orangtua. 


\section{PENGANTAR}

Anak dalam konteks sosial masyarakat di Indonesia seringkali dinilai sebagai harta yang berharga, begitu juga dalam masyarakat Jawa. Anak merupakan suatu anugerah yang sangat dinantikan kehadirannya oleh pasangan yang menikah, bahkan ketidakhadiran anak dalam konteks masyarakat Jawa bisa menyebabkan pasangan bercerai. Diutarakan oleh ElSaerodji (2011) sebagai bentuk wujud syukur akan kehadiran anak, para orangtua dalam masyarakat Jawa biasanya akan mewujudkan rasa syukur mereka dalam berbagai seremonial. Mulai dari saat kehamilan, kelahiran, ketika anak meninggalkan masa bayi dan bahkan saat anak menjelang masa pubertas. Kondisi ini menunjukkan betapa berharganya nilai anak dalam masyarakat Jawa, terutama bagi orangtua. Nilai anak menjadi suatu hal yang penting karena menurut Atmoko dan Setiono (2004) nilai anak di mata orangtua akan turut mempengaruhi bentuk pengasuhan yang akan dipilih orangtua dalam mengasuh anaknya. Nilai anak akan mempengaruhi bagaimana interaksi antara orangtua dengan anak (Dewi, 2013, Prasanti, 2013). Dampak tentang pentingnya pengasuhan orangtua terhadap perkembangan anak tidak perlu dipertanyakan lagi sudah teruji dalam banyak penelitian.

Cara pandang orangtua pada anak akan memunculkan harapanharapan yang akan diberikan pada anak bahkan ketika anak masih dalam kandungan. Segala hal baik diinginkan para orangtua ada pada anaknya. Orangtua ingin anaknya menjadi anak yang berguna, pandai, sukses, menjadi tauladan bagi lingkungan. Jadi penting untuk meneliti tentang nilai anak di mata orangtua. 
Sudah cukup banyak penelitian tentang nilai anak, namun demikian penelitian tentang nilai anak selama ini lebih banyak memusatkan perhatian pada nilai anak secara umum atau hanya pada orangtua dengan anak-anak normal ( antara lain: Dewi, 2013; Nurdianto, 2011; Prasanti, 2013; Syarifuddin, 2008; Wulandari, 2009). Selain itu juga penggunaan narasumber yang relatif sedikit, yaitu tidak lebih dari lima orang. Pada sisi lain masih sangat terbatas penelitian tentang nilai anak berkebutuhan khusus di mata pada orangtua. Orangtua mengharapkan akan mendapatkan anak yang terbaik namun tidak semua orangtua mendapatkan anak seperti yang diharapkan. Ada sebagian orangtua mau tidak mau harus menerima anak yang memiliki banyak kendala atau keterbatasan, yang disebut dengan anak berkebutuhan khusus (ABK). Jadi bisa disimpulkan bahwa penelitian tentang nilai ABK di mata orangtua dengan jumlah narasumber yang lebih banyak merupakan suatu hal yang urgen untuk dilakukan.

Berdasarkan uraian di atas maka pertanyaan penelitian yang diajukan adalah: "Bagaimana persepsi orangtua terhadap anaknya yang memiliki kebutuhan khusus?". Dengan demikian tujuan dari penelitian adalah melakukan eksplorasi terhadap nilai $A B K$ di mata orangtua. Manfaat dari penelitian adalah penemuan konsep dan indikator nilai $A B K$ di mata orangtua. Penemuan konsep dan indikator ini akan dapat dijadikan sebagai dasar penyusunan alat ukur nilai ABK yang kontekstual dengan masyarakat Indonesia, khususnya masyarakat yang tinggal di Jawa. Hal ini seperti yang dikatakan Mayer et al (2012), Mayer \& Trommsdorff (2010) bahwa nilai anak sangat dipengaruhi oleh konteks sosial budaya. Nilai anak akan berbeda pada konteks sosial dan budaya yang berbeda, sehingga untuk menyusun suatu 
alat ukur tentang nilai anak yang kontekstual maka harus didasarkan atas temuan pada masyarakat yang bersangkutan, bukan didasarkan atasa temuan dari konteks sosial budaya yang berbeda.

Hoffman \& Hoffman, 1973 (dikutip oleh Nauck, 2000) adalah orang yang pertama kali memunculkan konsep tentang nilai anak atau values of children. Mayer et al (2012), Mayer \& Trommsdorff (2010), serta Nauck (2000) mendefinisikan nilai anak sebagai cara orangtua memandang atau menilai anak, melihat kelebihan dan kelemahan memiliki anak, motivasi atau alasan apa yang melandasi orangtua memiliki anak. Beberapa temuan tentang nilai anak, antara lain dilakukan oleh Nauck (2000) yang menyimpulkan bahwa nilai anak bagi orangtua terbagi menjadi nilai anak secara psikologis, sosial dan ekonomi. Temuan lain menemukan nilai anak secara emotional, economic utilitarian dan normative (Mayer, Schwarz \& Trommsdorf; 2012). Mayer et al (2012), Mayer \& Trommsdorff (2010) melakukan kolaborasi penelitian dalam beberapa konteks sosial budaya yang berbeda, termasuk dengan Indonesia, mengatakan bahwa masyarakat dengan budaya Barat lebih banyak menilai anak secara emosional. Anak dinilai sebagai sumber kebahagiaan dan mendatangkan emosi positif pada orangtua. Dalam konteks sosial dan budaya Timur, termasuk Indonesia, anak dinilai sebagai economic utilitarian dan normative. Anak oleh orangtua lebih dinilai sebagai aset yang memberikan kontribusi pada pemasukan keuangan keluarga dan keamanan masa tua.

\section{METODE PENELITIAN}

Penelitian ini menggunakan pendekatan kualitatif. Data diperoleh melalui wawancara semi terstruktur yang dilakukan secara individual terhadap orangtua. Pertanyaan yang 
diajukan adalah: "Apa makna kehadiran (menyebutkan nama anak yang memiliki kebutuhan khusus) dimata bapak/ibu?". Responden penelitian adalah orangtua yang memiliki $\mathrm{ABK}$ usia kanak-kanak sampai remaja awal, paling kecil usia ABK 2 tahun 3 bulan dan paling besar usia ABK 13 tahun. Jenis gangguan yang dimiliki anak adalah spectrum autis, retardasi mental, tuna rungu, gangguan kesulitan konsentrasi dan hiperaktivitas (ADHD), keterlambatan bicara dan slow learner. Sebagai nara sumber adalah salah satu orangtua yang paling banyak terlibat dalam pengasuhan terhadap ABK. Jumlah nara sumber sebanyak 19 orang, dengan rincian ibu $(78,95 \%)$, ayah $(15,79 \%)$ dan kakek (5,3\%). Tingkat pendidikan nara sumber dari SD tidak lulus sampai sarjana. Usia nara sumber berkisar antara 29 tahun sampai 65 tahun. Data yang diperoleh hasil wawancara kemudian dianalisis secara kualitatif, melalui tahapan verbalisasi data, open coding, axial dan selective sebagai tahap akhir.

\section{HASIL PENELITIAN DAN PEMBAHASAN}

Berdasarkan hasil wawancara dengan nara sumber diperoleh temuan bahwa nilai ABK adalah bagaimana orangtua mempersepsikan atau menilai keberadaan anak dalam kehidupan mereka. ABK di mata orangtuanya dinilai secara: a) psikologis $(71,74 \%)$, b) religi $(17,39 \%)$, serta c) ekonomi $(10,87 \%)$.

Nilai anak secara psikologis adalah cara orangtua yang memaknai kehadiran anak secara psikologis, dengan indikator munculnya emosi-emosi, penerimaan, sosio psikologis, berpikir positif, harapan dan berharga..

Emosi adalah emosi-emosi secara personal yang muncul pada orangtua atas kehadiran anak, baik 
emosi positif maupun negatif. Emosi-emosi negatif nampaknya lebih banyak muncul pada orangtua daripada emosi positif. Hal ini muncul dalam ungkapan .... ...ya tadinya sebenarnya saya kaget mbak.... kok bisa seperti ini....anak itu gak salah, yang salah saya karena tidak mengetahui sejak awal...saya bisa menterapi anak orang lain tetapi tidak bisa menterapi anak sendiri...Cuma kadang ya saya jengkel ketika tahu......yo nek pertama kali yo...kecewa, mungkin ada rasa tidak adil, ya awalnya saya sedih... $(1,2,5,7$, 11). Namun pada sisi lain masih ada orangtua yang mampu menilai anaknya dengan emosi positif, muncul pada kasus 5, 8, 13 dan 18, antara lain dengan ungkapan ...saya itu tidak pernah membedakan anak saya yang autis dengan kakaknya...sama sayangnya...ketika asuransi menolak permintaan asuransi untuk anak saya yang autis..saya memutuskan semua anak juga tidak perlu ikut asuransi tersebut, ...sejak awal saya tidak kecewa ketika diberitahu kondisi anak saya...saya merasa bangga dipercaya memiliki anak...saya merasa terhibur dan senang dengan kehadiran anak saya.

Penerimaan orangtua adalah bagaimana orangtua menerima anak apa adanya dengan segala kelemahan yang ada, tanpa syarat. Penerimaan orangtua terhadap anaknya yang $\mathrm{ABK}$ antara lain diperkuat dengan munculnya ungkapan: ...ya dijalani saja...semarah apapun saya pada anak gak pernah saya bilang bodoh...ya kami terima apa adanya...ya pasrah aja (2, 5, 9, 12, 15). Penerimaan orangtua terhadap anaknya yang $\mathrm{ABK}$ bukan hal yang mudah, membutuhkan proses dan waktu yang lama, bahkan masih ada orangtua yang belum bisa menerima anak apanya, seperti diungkapkan kasus 2, 11 dan 14. Kami menerima tetapi secara bertahap...meskipun tidak mudah, 
lama-lama saya akhirnya bisa menerima anak apa adanya, ...awalnya saya sulit menerima...tetapi setelah itu bisa menerima... butuh waktu lama bagi saya bisa menerima...sebagai terapis saya bisa ndandani anak orang lain tetapi anak saya sendiri ndak bisa saya rubah...begitu sih awalnya...hampir 2 tahun saya baru bisa menerima kondisi anak saya setelah saya bawa kemanamana-mana...bahkan sampai sekarang nampaknya suami saya masih sulit menerima anak saya

Indikator berikutnya yang muncul dari nilai secara psikologis adalah sosio psikologis yaitu kondisi psikologis yang dirasakan atau muncul pada orangtua saat berada dalam lingkungan sosialnya. Ada orangtua yang yang merasakan anaknya sama saja dengan anak lain, tidak ada perbedaan dengan anak-anak pada umumnya, seperti muncul pada kasus 4, yang mengatakan...anak saya itu sama saja dengan anak lain...ya sama saja dengan anak pada umumnya...gak ada beda.... Saat berada bersama anak sebaya atau di luar rumah, beberapa orangtua merasakan malu, sungkan dan merasa anaknya memang berbeda, tidak normal, tidak sama dengan anak lain. Hal ini muncul dengan ungkapan...saya itu sering malu kalau lihat anak lain sudah bisa apa-apa, lebih mampu daripada anak saya...kok anak saya belum bisa bicara...saya sering malu dengan perilaku anak saya kalau bertamu atau bermain ke rumah tetangga...makanya saya lebih suka kalau anak saya gak bertemu orang lain... kadang ya saya sungkan dengan perilaku anak saya ...ya malu....terutama kalau pas pergi rumah tetangga....anak saya khan kalau masuk rumah orang seenaknya....dak pernah permsisi... mindah-mindah chanel teve tetangga semaunya padahal yang punya rumah sedang nonton teve....memarahi orang lain yang nonton sinetron karena dianggap 
gak penting... saya memang ngomong ke anak kalau nonton sinetron gak perlu, kadang saya gak enak sama orang lain...anak saya itu kalau ketemu orang lain khan suka bicara seenaknya... sering diam dan belum tentu mau menjawab kalau diajak bicara... bahkan bersalaman pun ndak mau kalau belum klik dengan orangnya... kadang responnya juga ndak tepat... misalnya ada orang jatuh... anak saya malah ketawa... saya jadi malu takut dikira ngajarin anak yang ndak bener... pas ketemu anak seusia... anak saya memang ndak sama dengan temannya yang normal... (1, 5, 6, 10). Ada kekurangannya... anaknya ndak kayak temen-temen yang seumuran... jawane durung ndolor... lha bapak ibune ndak sabaran... yo wes dimomong mbah aja (6)

Indikator aspek psikologis lain yang muncul adalah kemampuan orangtua untuk berpikir positif tentang anaknya yang $\mathrm{ABK}$, bahwa di tengah berbagai keterbatasan beberapa orangtua mampu menilai atau melihat sisi positif anak. Hal ini diperkuat dengan ungkapan ... Saya masih mensyukuri, banyak anak orang lain yang ndak normalnya lebih berat dari anak saya... saya itu bersyukur...meskipun anak saya berbeda dengan anak lain...tetapi anak saya itu tidak ketinggalan pelajaran di sekolah...tetap pinter menurut saya...saya bersyukur anak saya itu gak nakal, patuh dan nurut, tetap disyukuri pasti ada sisi positifnya anak (4. 10, 15, 16).

Indikator lain dari aspek nilai anak secara psikologis adalah harapan dan berharganya anak di mata orangtua. Harapan adalah keinginan atau harapan orangtua di masa depan terhadap anaknya, meskipun tahu kondisi anaknya yang memiliki kebutuhan khusus. Hal ini antara lain diperkuat dengan ungkapan...nek gedhe biso kerjo....bisa cari uang untuk kehidupan dia sendiri...saya 
pengen nanti сисu saya bisa seperti anak normal yang lain...ngomongnya lancar...bisa cari uang... bisa ngerjain apaapa sendiri (6), saya tidak akan menuntut anak saya untuk seperti anak normal pada umumnya...gak usah kayak anak normal ...mandiri... ...yang saya pentingin itu kemandiriannya...nggak lebih (7, 11). Indikator berharga adalah pandangan orangtua yang menilai bahwa apapun keadaannya anak tetap merupakan hal yang penting dan nomer satu dalam kehidupannya, karena tidak semua pasangan bisa memiliki anak dalam pernikahan mereka. Hal ini muncul dalam ungkapan..anak itu tetap nomer satu bagi saya...segalanya...penting...gak semua lho orang bisa punya anak (1).

Aspek nilai ABK lain yang muncul adalah nilai anak secara religi, yaitu penilaian orangtua bahwa kehadiran atau keberadaan anaknya yang ABK dalam keluarga dikaitkan dengan Tuhan. Indikator dari aspek nilai religi yang muncul adalah menilai anak sebagai anugerah, amanah dan ujian dari Tuhan. Keberadaan ABK sebagai anugerah muncul dengan ungkapan orangtua yang mengatakan.. anak ya sebagai anugerah...sebagai rejeki, semua anak adalah anugerah dari Gusti.. anugerah dari Tuhan ... $(3,13,14)$. Orangtua juga menilai anak sebagai amanah atau titipan Tuhan yang harus dijaga apapun kondisinya...sesuatu yang dipercayakan Tuhan pada kita untuk diasuh $(3,4,8)$. Kehadiran ABK dalam rumah tangga juga dinilai orangtua sebagai ujian dari Tuhan, seperti dikatakan oleh kasus 4 dengan ungkapan... anak ini khan ujian dari Tuhan buat saya...mampukah saya sabar...mampukah saya ndidik dia.

Aspek nilai ABK dengan persentase paling sedikit yang muncul dalam temuan ini adalah nilai secara ekonomi. Nilai anak 
secara ekonomi adalah penilaian orangtua bahwa kehadiran anak dalam keluarga mendatangkan suatu keuntungan bagi orangtua. Indikator nilai ekonomi yang muncul adalah kehadiran ABK dalam keluarga dinilai orangtua sebagai sarana untuk belajar dan penyemangat bagi orangtua untuk bekerja. Anak dinilai sebagai sarana untuk belajar antara lain muncul dalam bentuk ungkapan orangtua yang mengatakan...bagi saya...anak saya ini tempat belajar saya...kalau saya bisa belajar dari anak saya...anak saya itu tidak pendendam...lewat anak saya ...saya bisa menghargai hidup, buat saya belajar lebih sabar...sabar...dan sabar...saya lebih belajar untuk mengerti karakter orang $(2,16)$. Indikator lain dari nilai anak secara ekonomi adalah anak menjadi pendorong atau motivator bagi orangtua untuk bekerja. Hal ini seperti diungkapkan oleh kasus 9 dan 16. Anak itu apa ya....ya maknane ya dienggo semangat ya mbak... ben luweh rajin kerjo...yo anak nggowo rejekine dewedewe...nek balek kerjo... kesel... ndelok anak semangat kerja lagi, intinya harus kerja lebih keras untuk anak saya..anak saya khan butuh banyak biaya untuk terapi... jadi harus kerja lebih keras.

Sejauh sepengetahuan peneliti, temuan-temuan sebelumnya tentang nilai $\mathrm{ABK}$ di mata orangtua belum banyak ditemukan bahkan mungkin belum ada, sehingga untuk pembanding akan digunakan temuan-temuan nilai anak secara umum, bukan ABK. Riset dari luar Indonesia antara lain menemukan nilai anak secara psikologis, sosial dan ekonomi (Nauck, 2000), nilai anak secara emotional, economic utilitarian dan normative (Mayer, Schwarz \& Trommsdorf; 2012). Beberapa riset pada etnis Jawa menemukan nilai anak secara psikologis, sosial dan ekonomi (Prasanti, 2013; Handayani, 2011), anak sebagai anugerah Tuhan yang harus 
disyukuri dan dijaga (Wulandari, 2009), ekonomi, sosial dan budaya (Nurdianto, 2011). Dari beberapa penelitian tersebut dapat dilihat adanya konsistensi atau kesamaan antara temuan dari luar Indonesia maupun dari dalam Indonesia, yaitu nilai anak secara psikologis, sosial dan ekonomi. Sedangkan temuan yang khas untuk masyarakat Jawa namun tidak terdapat dalam temuan dari luar Indonesia adalah nilai anak secara religi. Apabila temuantemuan sebelumnya tersebut di atas dibandingkan dengan temuan penelitian ini maka terdapat kesamaan dan sekaligus juga perbedaan, baik temuan yang dari luar Indonesia maupun dalam Indonesia.

Konsistensi atau kesamaan dengan temuan sebelumnya (Handayani, 2011; Nauck, 2000; Mayer et al, 2012; Prasanti, 2013) adalah sama-sama menemukan nilai anak secara psikologis, dan ekonomi. Bila dicermati secara mendalam, meskipun terdapat kesamaan dimensi atau aspek antara penelitian ini dan penelitian-penelitian sebelumnya, namun tetap terdapat perbedaan indikator dalam aspek-aspek tersebut.

Dalam temuan sebelumnya, indikator nilai psikologis meliputi peraasaan senang dan bahagia akan kehadiran anak. Selain itu juga rasa bangga dan harapanharapan yang banyak terhadap anak. Dalam penelitian ini juga menemukan adanya rasa bangga dan harapan terhadap anak, namun indikator nilai psikologis dari temuan ini lebih banyak berkaitan dengan munculnya emosi-emosi negatif yang secara personal dirasakan orangtua akan keberadaan anak. Selain itu juga penerimaan orangtua akan kondisi anaknya yang memiliki kelemahan-kelemahan, kondisi psikologis yang dirasakan orangtua saat anak berada dalam lingkungan sosial dan kemampuan orangtua untuk tetap berpikir positif terhadap anaknya yang 
memiliki hambatan-hambatan perkembangan atau kebutuhan khusus. Orangtua merasa malu dengan keterbatasan perkembangan anak dibandingkan perkembangan anak sebaya yang lain, Selain itu juga muncul rasa sungkan ketika anak berada dalam lingkungan sosial karena anak menunjukkan perilaku yang tidak selaras atau berbeda dengan harapan lingkungan. Orangtua merasa bahwa anaknya berbeda dengan lain yang seusia.

Nilai anak secara ekonomi dalam temuan sebelumnya dimaknai sebagai pemahaman bahwa anak dilahirkan dan dibesarkan untuk membantu orangtua, baik dalam pekerjaan rumah tangga maupun pekerjaan orangtua. Anak juga dinilai sebagai investasi di masa tua, yaitu dengan berbakti dan merawat orangtua, membalas kasih sayang orangtua. Saat dewasa anak harus ganti memahami, peduli dan tidak menelantarkan orangtua, tahu dan bisa membantu orangtua. Sedangkan makna ekonomi dalam temuan ini bermakna anak yang memiliki kebutuhan khusus digunakan orangtua sebagai sarana untuk mencapai sesuatu yaitu sarana bagi orangtua untuk belajar menjadi orangtua yang lebih baik, menjadi orangtua yang lebih sabar dan menghargai kehidupan. Anak berkebutuhan khusus juga digunakan sebagai motivator atau penyemangat bagi orangtua untuk bekerja lebih giat untuk anak. Orangtua dengan anak berkebutuhan khusus tidak menilai anaknya yang $\mathrm{ABK}$ sebagai investasi masa depan.

Perbedaan dengan temuan sebelumnya dari luar Indonesia (Nauck, 2000; Mayer et al, 2012) adalah dengan ditemukannya nilai anak secara religi dalam temuan ini. Pada sisi lain temuan akan nilai anak dengan dimensi atau aspek religi ini konsisten dengan temuan sebelumnya yang dilakukan dalam konteks masyarakat Jawa oleh Wulandari 
(2009). Anak adalah amanah, anugerah dan titipan dari Tuhan yang harus dijaga dan diasuh dengan baik, apapun kondisinya. Dalam konteks masyarakat Timur, termasuk masyarakat Jawa, religi nampaknya merupakan bagian yang tidak terpisahkan dengan kehidupan masyarakat. Religi merupakan bagian yang penting dan fundamental dalam kehidupan manusia, sehingga ada ungkapan yang mengatakan bahwa manusia bisa berusaha namun Tuhan lah yang tetap menentukan hidup mati, jodoh dan takdir manusia. Dalam hal ini termasuk kehadiran anak dalam keluarga, baik anak berkebutuhan khusus maupun tidak.

Perbedaan lain antara temuan ini dengan temuan sebelumnya adalah nilai anak secara budaya/biologis. Nurdianto (2011) dengan konteks masyarakat di Kabupaten Banjanegara menemukan bahwa selain ekonomi dan sosial, orangtua juga memaknai kehadiran anak secara budaya/biologis. Anak dipandang sebagai penerus keturunan, meneruskan tradisi, menjaga generasi agar tidak hilang, dan untuk meneruskan nama keluarga. Nilai anak secara biologis/budaya ini tidak muncul dalam temuan ini. Perbedaan ini muncul kemungkinan karena objek yang dinilai orangtua berbeda. Nurdianto melihat nilai anak secara normal atau pada umumnya, sedangkan temuan ini fokus pada penilaian orangtua terhadap kehadiran anaknya yang memiliki kebutuhan khusus $(\mathrm{ABK})$. Orangtua yang memiliki ABK nampaknya menyadari bahwa tidak mungkin bagi anak mereka yang ABK untuk kelak di kemudian hari menikah seperti orang normal pada umumnya, sehingga para orangtua tidak memiliki harapan atau membebankan pada anaknya yang ABK untuk meneruskan keturunan atau menjaga generasi agar tidak hilang. Harapan utama orangtua adalah anak bisa 
mengurus dirinya sendiri, mandiri dan tidak tergantung dengan orang lain.

\section{KESIMPULAN}

Berdasarkan hasil penelitian dan pembahasan tersebut di atas maka dapat dibuat simpulan bahwa nilai ABK di mata orangtuanya adalah bagaimana cara orangtua menilai atau memaknai kehadiran anak berkebutuhan khusus dalam kehidupannya. ABK oleh orangtuanya dinilai secara psikologis, religi dan ekonomi. Temuan yang konsisten dengan temuan sebelumnya, baik dari luar maupun dalam Indonesia adalah nilai anak secara psikologis dan ekonomi. Temuan yang khas dalam temuan ini dan konsisten dengan temuan dalam konteks masyarakat Jawa adalah nilai anak secara religi. Aspek atau dimensi yang tidak ditemukan dalam penelitian nilai $\mathrm{ABK}$ ini adalah aspek biologis/sosiakultural.
Beberapa saran yang perlu dilakukan untuk pengembangan hasil temuan ini adalah:

1. Penemuan aspek dan indikator dalam temuan bisa dijadikan dasar untuk penyusunan skala psikologis tentang nilai anak berkebutuhan khusus, yang kemudian diujicobakan dengan pendekatan kuantitatif sehingga akan diperoleh skala psikologis yang teruji validitas dan reliabilitasnya.

2. Bagi para peneliti yang akan menggunakan aspek dan indikator yang ditemukan dalam temuan ini sebagai dasar untuk penyusunan skala psikologis, perlu mempertimbangkan bila akan menggunakan skala ukur di luar kontek masyarakat Jawa karena penelitian ini dilakukan di kota Semarang dengan keseluruhan subjek penelitian berasal dari suku Jawa.

3. Hasil penelitian yang lebih komprehensif atau menyeluruh juga akan bisa dicapai bila 
lokasi penelitian diperluas lagi, bila perlu dalam ruang lingkup yang lebih besar di luar Jawa. Sebagai negara yang multikultural maka akan sangat menarik bila diperoleh nilai ABK dari berbagai konteks sosial budaya di Indonesia.

\section{DAFTAR PUSTAKA}

Atmoko, A. \& Setiono, K. 2004. Nilai anak, identitas vokasional, dan gaya pengasuhan pada petani pesanggem di masyarakat pinggiran hutan zoja penyangga Taman Nasional Bromo-TenggerSemeru: Studi perspektif psikologi perkembangan antargenerasi. Forum Penelitian: Jurnal Teori dan Praktek Penelitian Lemlit Universitas Negeri Malang. (Abstrak). Diakses dari http://library.um.ac.id/majalah/p rintmajalah4.php/29806.html pada tanggal 14 November 2013.

Dewi, W.C. 2013. Nilai anak pada ibu dewasa madya etnis Jawa ditinjau dari tingkat pendidikan. Calypta: Journal ilmiah Mahasiswa Universitas Surabaya. Volume 2, No.1.
El-Sarodji, D.A.F. (2011). Pertumbuhan dan perkembangan anak: Perpektif sosial budaya Jawa. Diakses dari http://atfahmi.kemsos.org/2011/ 01/27/pertumbuhan-danperkembangan... pada tanggal 14 November 2013.

Handayani, O.W.K. 2011. Nilai anak dan jajanan dalam konteks sosiokultural: studi tentang status gizi balita pada lingkungan rentan gizi di desa Pucuk Kecamatan Mijen Kabupaten Demak Jawa Tengah. Disertasi. Salatiga: UKSW. Diakses dari

http://repository.library.uksw.ed $\underline{\mathrm{u} / \text { handle/123456789/723 }}$ pada tanggal 14 November 2011.

Mayer. B., Schwarz, B. \& Trommsdorff, G. 2012. Value of children and intergenerational relationships: culture-level relationshop in two generation.

Dipresentasikan dalam Workshop Value of Children and Intergenerational

Relationship di Universitat Konstanz. Diakses dari http://www.psychology.uni.kons tanz.de/index.php?eID=tx...u... Pada tanggal 17 November 2013.

Mayer, B. \& Trommsdorff,G. 2010. Adolescents'value of children and their intention 
to have children: A cross cultural and multilevel analysis. Journal of CrossCultural Psychology. Vol. 41, 5-6, pp. 671-689. Diakses dari http://dx.doi.org/10.1177/0 022022110372195

Nauck, B. 2000. The changing value of children - a special action theory of fertility behavior ang intergenerational relationships in crosscultural comparison. Paper dipresentasikan dalam seminar "Low Fertility, families and public policies". Organized by the Europian Observatory on Familiy Matters in Sevilla, september 15-16.

Nauck, B. \& Klaus, D. 2007. The varying value of children: Empirical result from eleven societies in Asia, Africa and Eropa. Current Psychology.Vol. 55 (44), 487-503. Doi: $10.1177 / 001139210707763$ 4

Nurdianto, A.A. 2011. Persepsi tentang nilai anak dalam keluarga kaiatannya dengan tingkat pendidikan orangtua di Kelurahan Argasoka Kecamatan banjarnegara Kabupaten Banjarnegara tahun 2010. Under graduates thesis. (Abstrak). Publish version. Universitas Negeri Semarang. Diakes dari http://lib.unnes.ac.id/14664 pada tanggal 17 November 2013.

Prasanti, M.D. 2013. Nilai anak pada ibu dengan status sosial ekonomi tinggi ditinjau dari etnis Jawa. Calypta: Journal ilmiah Mahasiswa Universitas Surabaya. Volume 2, No.1.

Syarifuddin. H. 2008. Pengasuhan dalam masyarakat Jawa di Jawa. Diakses dari http://masdayat.web.id/2008/12/ pengasuhan-dalam-masyarakatjawa... pada tanggal 14 November 2013.

Trommsdorff, G., Kim, U., \& Nauck, B. 2005. Factors influencing value of children and intergenerational relations in times of social change: Analysis from psychological and sociocultural perspective: Introduction to the special issue. Applied Psychology. Vol. 54 (3), 313-316.

Wulandari, D.D. 2009. Nilai anak bagi orangtua dan dampak terhadap pengasuhan. Skripsi. (Abstrak). Universitas Muhammadiyah Surakarta. Diakses dari http://etd.eprints.ums.ac.id/4884 $\perp$ pada tanggal 17 November 2013. 